\title{
EFFECT OF SWIMMING ON INCREASING OF CARDIO- RESPIRATORY CAPACITY IN PARAPLEGICS
}

\author{
By Adam Pachalski and Tadeusz Mekarski \\ Rehabilitation Institute, Academy of Physical Education in Craców, Poland
}

\begin{abstract}
The aim of this paper was to study the effect of swimming training on the cardio-respiratory system of paraplegics. The observation of 60 paraplegics ( 34 males and 26 females) was carried out during the three years experiment. To measure a cardiorespiratory efficiency level we used Skibinski's cardio-respiratory index (SCRI). After three years of the swimming training programme the SCRI value increased four times.
\end{abstract}

Key words: Swimming of paraplegics; Training programme; Training intensity; Skibinski's cardio-respiratory index (SCRI).

ANY sport activity permits paraplegics to maintain the physical efficiency level which was obtained during a medical rehabilitation. Sport is the best way to improve the physical efficiency because it allows a proper effort dosage. A disabled person finds energy and psychological motivation in possibility of competition with other disabled persons who have a similar kind of disability. A value of sport activity of paraplegics was positively accepted by such authorities as Sir L. Guttmann, Professor Dega and Professor Weiss.

The International Stoke Mandeville Games are the world's biggest competition for paraplegics and they entirely confirm Sir Ludwig's idea (Guttmann, 1976). For several years Polish athletes have been successfully performing in this meeting, gaining many medals, especially in swimming.

Sport Association 'START' in Craców closely collaborates with Rehabilitation Institute of Academy of Physical Education in Craców, and it is managing entire sports activity of disabled persons in the southern part of Poland. This cooperation permitted us to work out some elements of learning which confirmed the necessity of taking a broad view of rehabilitation problems and including regular sport training for such purpose (Pachalski, 1970). Using this method we obtained good results and we would like to present some of the examples.

Miss A. T. -26 years old, gained 36 medals in the most important world's meetings. She beat 17 records in swimming.

Mr A. S.-I7 years old, had attended a regular training programme in swimming for 4 years. He was the winner of all gold medals in swimming during the Polish Championship in 1978, and he beat unofficially world records in all distances and strokes. He competed successfully with healthy swimmers. Miss A. T. and Mr A. S. represent a group of 30 disabled persons who were observed during the three years experiment.

\section{Material and Methods}

The observation of 60 paraplegics ( 34 males and 26 females) was carried out during the three years experiment. All persons were between 18-27 years old and they attended a rising efficiency programme in Rehabilitation Centre in Craców. 
The basic intervention was realised under medical control and included passive exercises, passive redressment exercises, active relieving exercises, resting exercises, learning of walking, learning of pushing a wheelchair, general efficiency exercises, conventional massage and physiotherapeutic treatment.

Full intervention unit was 2.5 hours long and was executed 2-3 times a week. Thirty persons who were able to do some primitive movements in a swimming pool and who felt the willingness to start a regular training programme in swimming were chosen from the whole group.

After completion of an adaptation period this group started a regular training programme in swimming. In further considerations this group will be named 'group A'. 'Group B' included 30 other persons who continued the conventional form of rehabilitation programme. The data obtained from the examinations of both groups were analysed at the beginning of the experiment and after three years.

Work programme for the experimental group ' $A$ '

In adaptation programme all disabled persons had accustomed themselves to water and learned to swim with at least 2-3 strokes. After completion of this adaptation period this group started a regular swimming in which an increasing of training intensity and unit training time was realised. We present the data obtained during the last year of the experiment, showing weekly and annual averages of training loads.

\section{Course Stages}

Stage I-from Sept. I to Dec. 2I (I6 weeks)

Macrocycles:

I. General preparation, Sept. I-Oct. 5 ( 5 weeks) 6 hours of swimming a week.

2. Endurance preparation, Oct. 6-Nov. 2 (4 weeks) 6 hours of swimming a week.

3. Specialistic preparation, Nov. 3-Nov. 30 (4 weeks) 6 hours of swimming a week.

4. Endurance preparation for competition period, Dec. I-Dec. 2 I (3 weeks) 6 hours of swimming a week.

Stage II-from Dec. 22 to April 4 (I5 weeks)

Macrocycles:

5. Specialistic endurance training, Dec. 22-Jan. I 7 ( 4 weeks) 6 hours of swimming a week.

6. Specialistic endurance and quickness training, Jan. I8-Feb. I5 (4 weeks) 6 hours of swimming a week.

7. 2 weeks of training centre, 18 hours of swimming a week.

8. Direct preparation for competition period, Feb. I6-March 6 (3 weeks) 6 hours of swimming a week.

9. Competition period, March 7-April 4 (4 weeks) 6 hours of swimming a week.

Stage III-from April 5 to Aug. 29 (2I weeks)

Macrocycles:

I0. Endurance training, April 5-May 2 (4 weeks) 6 hours of swimming a week.

I I. Specialistic endurance training, May 3-June 27 (8 weeks) 6 hours of swimming a week. 
I2. Direct preparation for competition period, June 28-July I8 (3 weeks) 6 hours of swimming a week.

13. Competition period, July I9-Aug. I5 (4 weeks) 6 hours of swimming a week. I4. Transitional period, Aug. I6-Aug. 29 (2 weeks) 6 hours of swimming a week.

The average of training content unit ( 45 minutes) varies: in the stage I: I200I 400 metres, $7 \cdot 2-8 \cdot 4 \mathrm{~km}$ a week; in the stage II and III: I200-I600 metres, $7 \cdot 2-9 \cdot 6$ $\mathrm{km}$ a week.

TABLE I

The average of training intensity

\begin{tabular}{|c|c|c|c|c|c|c|c|c|c|}
\hline \multirow{2}{*}{$\begin{array}{l}\text { Macro- } \\
\text { cycles }\end{array}$} & \multirow{2}{*}{$\underset{\mathrm{km}}{\operatorname{annually}}$} & \multicolumn{4}{|c|}{$\%$} & \multicolumn{4}{|c|}{$\mathrm{km}$} \\
\hline & & A & B & C & $\mathrm{D}$ & A & B & C & $\mathrm{D}$ \\
\hline I & $36-42$ & 5 & 30 & 45 & 20 & $I \cdot 8-2 \cdot I$ & $10 \cdot 8-12.6$ & $16 \cdot 2-18 \cdot 9$ & $7 \cdot 2-8 \cdot 4$ \\
\hline 2 & $28 \cdot 8-33 \cdot 6$ & & & & & $\mathrm{I} \cdot 4-\mathrm{I} \cdot 7$ & $8 \cdot 6-10 \cdot 0$ & $13 \cdot 0-15 \cdot 1$ & $5 \cdot 7-6 \cdot 7$ \\
\hline 3 & $28 \cdot 8-33 \cdot 6$ & & & & & $I \cdot 4-I \cdot 7$ & $8 \cdot 6-10 \cdot 0$ & I3.0-I5.I & $5 \cdot 7-6 \cdot 7$ \\
\hline 4 & $21 \cdot 6-25 \cdot 0$ & & & & & $I \cdot I-I \cdot 2$ & $6 \cdot 4-7 \cdot 5$ & $9 \cdot 7-\mathrm{II} \cdot 3$ & $4 \cdot 3-5 \cdot 0$ \\
\hline 5 & $28 \cdot 8-38 \cdot 6$ & IO & 40 & 35 & 15 & $2 \cdot 9-3.9$ & II $\cdot 5-15 \cdot 4$ & IO.I-I3.5 & $4 \cdot 4-5 \cdot 5$ \\
\hline 6 & $14 \cdot 4-19 \cdot 2$ & & & & & $I \cdot 4-I \cdot 9$ & $9 \cdot 6-7 \cdot 6$ & $5 \cdot I-6 \cdot 7$ & $2 \cdot I-2 \cdot 8$ \\
\hline & $43 \cdot 2-57 \cdot 6$ & & & & & $4 \cdot 3-5 \cdot 8$ & $17 \cdot 2-23 \cdot 0$ & I $5 \cdot I-20 \cdot I$ & $6 \cdot 4-8 \cdot 6$ \\
\hline 7 & $2 \mathrm{I} \cdot 6-28 \cdot 8$ & & & & & $2 \cdot 2-2 \cdot 9$ & $8 \cdot 5-\mathrm{II} \cdot 4$ & $7 \cdot 5-10 \cdot 0$ & $3 \cdot 2-4 \cdot 3$ \\
\hline 8 & $28 \cdot 8-38 \cdot 6$ & & & & & $2 \cdot 9-3.9$ & II $5-15 \cdot 4$ & $10.1-13.5$ & $4 \cdot 3-5 \cdot 8$ \\
\hline 9 & $28 \cdot 8-38 \cdot 6$ & I5 & 45 & 30 & IO & $4 \cdot 4-5 \cdot 8$ & I3.0-I7.4 & $8 \cdot 6-\mathrm{II} \cdot 5$ & $2.9-3.9$ \\
\hline IO & $57 \cdot 6-76 \cdot 8$ & & & & & $8 \cdot 6-\mathrm{II} \cdot 5$ & $25 \cdot 9-34 \cdot 5$ & $17 \cdot 2-23 \cdot 0$ & $5 \cdot 8-7 \cdot 7$ \\
\hline I I & $7 \cdot 2-9 \cdot 6$ & & & & & $\mathrm{I} \cdot \mathrm{I}-\mathrm{I} \cdot 4$ & $3 \cdot 2-4 \cdot 3$ & $2 \cdot I-2 \cdot 9$ & $9 \cdot 7-10 \cdot 9$ \\
\hline & $21 \cdot 6-28 \cdot 8$ & & & & & $3 \cdot 2-4 \cdot 3$ & $9 \cdot 7-13 \cdot 0$ & $6 \cdot 4-8 \cdot 6$ & $2 \cdot I-2 \cdot 8$ \\
\hline I 2 & $28 \cdot 8-38 \cdot 6$ & & & & & $4 \cdot 4-5 \cdot 8$ & $13 \cdot 0-17 \cdot 4$ & $8 \cdot 6-\mathrm{II} \cdot 5$ & $2.9-3.9$ \\
\hline I3 & I $4 \cdot 4-19 \cdot 2$ & & & & & $2 \cdot I-2 \cdot 8$ & $6 \cdot 4-6 \cdot 7$ & $4 \cdot 3-5 \cdot 8$ & $I \cdot 4-I \cdot 9$ \\
\hline
\end{tabular}

We suggest swimming frequency 4-6 times a week according to presented schedule and coach's advice.

\section{Determination of training intensity level}

A. Submaximal-maximal intensity

I. About 90-I00 per cent of maximal capacity, individualised for each swimmer and for each distance or stretch.

2. The pulse rate -29 or more per Io sec.

B. Strong intensity

I. About 80-90 per cent of maximal capacity.

2. The pulse rate about $26-28$ per Io sec.

C. Low intensity

I. Below 70 per cent of maximal capacity; it means the relaxing swimming, but with basic technical control of stroke.

2. The pulse rate -20 and lower per Io sec. 
The aim of this paper was to study the effect of swimming training on the cardio-respiratory system of paraplegics.

To measure a cardio-respiratory efficiency level we used Skibinski's cardiorespiratory index (SCRI) (Czabanski, I960).

$$
\mathrm{SCRI}=\frac{0.0 \mathrm{IVC} \times \mathrm{AT}}{\mathrm{PR}}
$$

where: $\quad \mathrm{VC}=$ vital capacity (in millilitres)

$\mathrm{AT}=$ apnoea time (in seconds)

$\mathrm{PR}=$ pulse rate

SCRI has been widely used either in phthisiology or medical examinations of athletes (Grynszpan, I966). In healthy persons SCRI varies from I2 to I00 (Czabanski, I960). Only ascertainment of low SCRI values is of practical importance. A failure of cardio-respiratory system should be considered when the SCRI values below Io are observed. The SCRI values below 6 indicate a cardiorespiratory insufficiency.

SCRI components were measured in the following order: the pulse rate, vital capacity and apnoea time. Each component measurement was repeated three times.

To interpret observed changes of SCRI values in both groups 'A' and ' $B$ ' we analysed the data with some statistical tests (Guilford, I964).

\section{TABLE II}

\begin{tabular}{lrrr}
\hline & \multicolumn{2}{c}{$\begin{array}{c}\text { Statistical } \\
\text { indexes }\end{array}$} & $\begin{array}{c}\text { Number of } \\
\text { observations }\end{array}$ \\
\cline { 2 - 3 } & $\mathrm{X}$ & $\mathrm{EX}$ & \\
\hline Initial examinations $\mathrm{A}_{1}$ & $8 \cdot 3$ & 3.9 & $\mathrm{~N}=30$ \\
Final examinations $\mathrm{A}_{2}$ & $36 \cdot 7$ & $\mathrm{IO} \cdot 8$ & $\mathrm{~N}=30$ \\
Initial examinations $\mathrm{B}_{1}$ & $6 \cdot \mathrm{I}$ & 3.3 & $\mathrm{~N}=30$ \\
Final examinations $\mathrm{B}_{2}$ & $\mathrm{IO} \cdot 8$ & 6.8 & $\mathrm{~N}=30$ \\
\hline
\end{tabular}

where: $\mathrm{X}=$ arithmetical mean of SCRI

$\mathrm{EX}=$ Standard (error) deviation

The significance level of differences between the arithmetical means obtained from the examination data in groups 'A' and 'B' was analysed by Student $t$ test.

The comparison between the following examinations data was carried out:

$\mathrm{A}_{1}-\mathrm{A}_{2}$-experimental group: the data obtained from the initial and final examinations.

$A_{1}-B_{1}$-experimental group and control group: the data obtained from the initial examinations.

$\mathrm{A}_{2}-\mathrm{B}_{2}$-experimental group and control group: the data obtained from the final examinations.

$\mathrm{B}_{1}-\mathrm{B}_{2}$-control group: the initial and final examinations. 
TABLE III

\begin{tabular}{cc}
\hline Groups & Student $t$ value \\
\hline $\mathrm{A}_{1}-\mathrm{A}_{2}$ & 2.47 \\
$\mathrm{~A}_{1}-\mathrm{B}_{1}$ & 0.43 \\
$\mathrm{~A}_{2}-\mathrm{B}_{2}$ & 2.02 \\
$\mathrm{~B}_{1}-\mathrm{B}_{2}$ & 0.62 \\
\hline
\end{tabular}

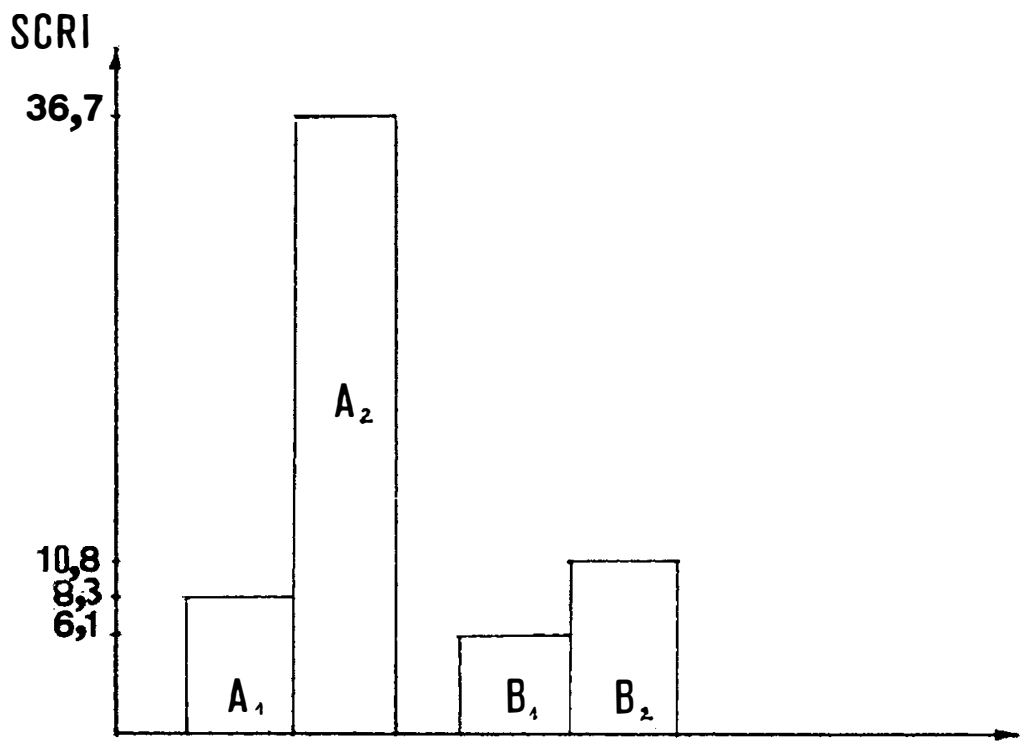

FIG. I

Increasing of SCRI values in groups A and B.

\section{Conclusion}

I. At the beginning of this experiment we found a low cardio-respiratory efficiency level in both groups ' $A$ ' and ' $B$ '. The difference between these groups was insignificant.

2. After 3 years of the rehabilitation programme the value of SCRI's arithmetical mean was insignificant.

3. After 3 years of the swimming training programme the SCRI value increased four times. The difference was between significance level and high significance level.

4. At the end of the experiment the SCRI values indicate the significant difference between both groups.

5. At the end of the experiment an increasing of vital capacity and apnoea time was observed in group ' $A$ ' while the pulse rate decreased simultaneously in the same group. Since a significant increasing of SCRI was observed after 3 years of training, an essential improvement of cardio-respiratory capacity level should be considered in group ' $A$ '. 
Our experiences inspired by Sir Ludwig's idea (Guttmann) showed advantage of a swimming training programme in rehabilitation of paraplegics. We consider the regular swimming training programme as one of the best methods of paraplegics rehabilitation because it permits all disabled persons to improve their efficiency level and even become champions.

\section{SUMMARY}

The main aim of this paper was to study the effect of swimming training programme on cardio-respiratory capacity level of paraplegics. After an adaptation period 30 disabled persons participated in a regular training programme in swimming for 3 years. At the end of experiment an increasing of vital capacity and apnoea time was observed in this group while the pulse rate decreased simultaneously. In the experimental group the SCRI value increased four times when comparing with SCRI value of control group.

A methodical plan of a regular training programme in swimming adapted for paraplegics is presented in this paper.

\section{RÉSUMÉ}

L'influence de l'entraînement en natation sur l'augmentation de la capacité cardiorespiratoire de paraplégiques fut le plus important but de ce rapport.

Les expériments furent menés avec 30 invalides à travers 3 ans de l'entraînement en natation, après un période de l'adaptation. Après ce période on a constaté l'augmentation de la capacité vitale, accroissement de l'apnée et la chute de pouls pour une minute.

L'indicateur de Skibinski a augmenté quatre fois en comparant avec les malades qui étaient réhabilités dans la traditionnelle méthode de la réhabilitation motrice.

Dans cette élaboration on présente le programme de l'entraînement en natation pour les paraplégiques.

\section{ZUSAMMENFASSUNG}

Die Arbeit hatte Ziel, einen Einfluss des Schwimmtrainings auf die Steigerung der Kreislauf- und Atmungsfähigkeit bei den Paraplegiken festzustellen.

Einem Experiment wurden 30 Inwaliden unterzogen, mit denen man nach der Adaptationszeit das Schwimmtraining binnen drei Jahren durchführte.

Bei den Untersuchungen in der Experimentalgruppe kann man nach drei Jahren folgendes feststellen:

- Vergrösserung der Lungenkapazität

- Verlangerung der Atmungszeit

- Sinkung der Pulsfrequenz auf eine Minute.

Die Kennziffer von Skibinski ist zweimal doppelt gestiegen, im Vergleich zu jener Gruppe, die dem Rehabilitationsprozess in traditioneller Form Bewegungsbesserung unterzogen wurde. In der Arbeit werden methodische Bearbeitungen des Schwimmtrainings bei den Paraplegiken angegeben.

\section{REFERENCES}

Czabanski, B. (1960). Wspólczynnik krazeniowo-oddechowy Skibinskiego u mlodziezy uprawiajacej sport plywacki. Warszawa.

DEgA, W. (I968). Ortopedia i rehabilitacja. PZWL, Warszawa.

DEGA, W. (1963). Ruch jako czynnik leczenia. Warszawa.

DEGA, W. (1968). Rola wychowania fizycznego, sportu $i$ rehabilitacji medycznej $i$ spolecznej. Warszawa.

GrynszPAN, A., KNAP, I. (1966). Badania nad zaleznoscia miedzy testem Cramptona a wskaznikiem krazeniowo-od-dechowym Skibinskiego u chorych $z$ niedowładami $i$ porazeniami miesni konczyn dolnych po poliomy elitis anterior acuta Chirurgia Narz. Ruchu i Ort. Pol. 
GuILFoRD, I. (I964). Podstawowe metody statystyczne w psychologii $i$ pedagogice, Warszawa. Guttmann, L. (1976). Textbook of Sport for the Disabled, England. Published by HM+M, Publishers Ltd.

Guttmann, L. Water therapy and water sport for the physically handicapped. Proc. Ann. Conf. Inst. Bath. Management, Blackpool, 67 pp., 288-289.

Guttmann, L. Sport for the Disabled as a World Problem. Rehabilitation, 68, 23-43.

PACHALSKI, A. (1970). Znaczenie cwiczen fizycznych $i$ sportu dla zdrowia $i$ utrzymania wysokiej sprawnosci organizmu inwalidy. Kraków.

WeIss, M. (1965). Podstawowe zagadnienia rehabilitacji schorzen narzadu ruchu. Warszawa. 